\title{
Overexpression and unique rearrangement of VH2 transcripts in immunoglobulin variable heavy chain genes in ankylosing spondylitis patients
}

\author{
Yeon Joo Kim ${ }^{1 *}$, Nayoung Kim ${ }^{1 *}$, Min-Kyung Lee ${ }^{2}$, \\ Hyo-Jin $\mathrm{Choi}^{2}$, Han Joo Baek ${ }^{2,3}$ and \\ Chang-Hoon $\mathrm{Nam}^{1,3}$ \\ ${ }^{1}$ Korea Institute of Science and Technology - \\ Europe Forschungsges. $\mathrm{mbH}$ \\ Saarbücken, Germany \\ ${ }^{2}$ Department of Rheumatology \\ Gachon University School of Medicine \\ Gil Hospital \\ Incheon 405-760, Korea \\ ${ }^{3}$ Corresponding authors: Tel, 49-681-9382-416; \\ Fax, 49-681-9382-279; E-mail, chang @ kist-europe.de (C.H. Nam), \\ Tel, 82-32-460-8426; Fax, 82-32-469-4320; \\ E-mail, baekhj@gilhospital.com (H.J. Baek) \\ ${ }^{*}$ These authors contributed equally to this work. \\ DOI 10.3858/emm.2010.42.5.030 \\ Accepted 10 February 2010 \\ Available Online 22 February 2010
}

Abbreviations: AS, ankylosing spondylitis; $C$, constant region; CDC42 BPB, CDC42 binding protein kinase beta; D, diversity gene segment; $\mathrm{H}$, heavy chain; HuPo, human acidic ribosomal protein; $J$, joining gene segment; L, light chain; Q-PCR, quantitative real-time PCR; RSS, recombination signal sequences; V, variable region; $\mathrm{VH}$, variable heavy chain

\footnotetext{
Abstract

To identify immunoglobulin variable heavy chain (VH) gene usages in Korean ankylosing spondylitis (AS) patients, expression level of $\mathrm{VH} 2$ genes from peripheral blood mononuclear cells (PBMCs) of 8 AS patients and 9 healthy donors was analysed by quantitative real-time PCR (Q-PCR). Q-PCR results demonstrated VH2 genes were overexpressed in AS patients (Relative amount of mRNA of VH2 genes to a house-keeping gene, $7.13 \pm 7.77$ vs, $0.68 \pm 0.55 ; P$ $<0.0001)$. The sequence analysis revealed the majority of them contained CDC42 binding protein kinase beta (CDC42 BPB) genes. The insertion of CDC42 BPB gene was confirmed by $P C R$ with primers corresponding $\mathrm{CDC} 42 \mathrm{BPB}$ and $\mathrm{CH}$ genes. Our study revealed VH2 overexpression and unique rearrangement in $\mathrm{lg} \mathrm{VH}$ genes from peripheral blood of AS patients. This may
}

imply aberrant immunoglobulin gene rearrangement in B cell occurs in Korean AS patients, which requires further investigation.

Keywords: spondylitis, ankylosing; gene rearrangement, B-Lymphocyte, heavy chain; immunoglobulin variable region; reverse transcriptase polymerase chain reaction

\section{Introduction}

Ankylosing spondylitis (AS), a prototype of spondyloarthritis (SpA), is a chronic inflammatory arthritis that mainly affects the sarcroiliac joints and the spine. It is characterized by peripheral arthritis, enthesitis, and extraskeletal features, such as uveitis and inflammatory bowel disease. The pathogenesis of AS/spondyloarthritis is not fully elucidated, but much has been learned regarding this condition in recent decades. Human leukocyte antigen (HLA)-B27, an MHC class I allele, is a key genetic factor in AS/spondyloarthritis (Brewerton et al., 1973; Schlosstein et al., 1973). Enteric bacteria may also play a role in causing the diseases as an environmental component (Taurog et al., 1994; De Keyser et al., 1998). Populations of immune cells have been implicated in the pathogenesis of AS/spondyloarthritis. T cells, particularly $\mathrm{CD}^{+}{ }^{+} \mathrm{T}$ cells, are required for developing the disease in rats (Breban et al., 1996; May et al., 2003). There has been evidence that macrophages participate in the pathogenesis of the disease (Baeten et al., 2002; McGonagle et al., 2002). Recent data have demonstrated that Th17 cells, IL-17-producing effector T helper cells, contribute to AS/ spondyloarthritis inflammation (Jandus et al., 2008; Shen et al., 2009). However, specific autoantibodies have not yet been identified in patients with AS/spondyloarthritis, and the role or relevance of $B$ cells in the pathogenesis of the disease is unclear.

Analyses of immunoglobulin variable region $(\mathrm{V})$ gene usages have revealed differences in the basic Ig $V$ repertoire of patients with $B$ cell- and/or $T$ cell-mediated autoimmune diseases, including systemic lupus erythematosus (Isenberg et al., 1993; Stevenson et al., 1993), myasthenia gravis (Sims et al., 2001), rheumatoid arthritis (Robbins et 
al., 1990; Ermel et al., 1997), and Sjögren syndrome (Dorner et al., 2002), compared to healthy controls. Such differences could be derived from intrinsic abnormalities in the generation of $\mathrm{lg} V$ genes or B cell development and functions (Foreman et al., 2007). Thus, the analysis of Ig $\vee$ gene usages can offer new insights into possible pathogenic role of $B$ cells in diseases.

A previous study of heavy chain variable segment $(\mathrm{VH})$ germline gene usages in synovial $B$ cells from AS patients demonstrated that the majority of rearranged $\mathrm{Ig} \mathrm{VH}$ genes belonged to the VH3 genes (Voswinkel et al., 2001). However, it did not include a direct comparison to healthy donors and some of the VH germline genes were overlooked due to the incomplete VH PCR primer sets. Therefore we investigated $\mathrm{VH}$ germline gene usages of patients with AS compared to healthy donors using PCR with additional primer sets.

\section{Results}

\section{Profile of subjects}

The demographic and clinical characteristics of patients and controls are shown in Table 1. The mean age of AS patients was older than controls (38.6 and 30.2 years, respectively), but it was not statistically significant.

\section{Overexpressed $\mathrm{VH}^{*}$ genes in AS patients}

To analyze $\mathrm{VH} 2$ gene usages in detail, Q-PCR was performed with RNA from PBMC in AS patients. After we checked out that primer sets used in previous studies (Voswinkel et al., 2001) can cover $\mathrm{VH}$ germline sequence from Ig Blast databases, we realized that 8 sequences of IGHV2 subfamilies (IGHV2-5*01, 5*04, 5*05, 5*06, 5*07, 5*10, 70*09 and $70^{*} 12$ ) and 10 sequences of IGHV4 subfamilies (IGHV4-34*01,34*03,34*04, 34*05, 34*06, $34^{*} 07,34^{*} 08,34^{*} 11,34^{*} 12$ and $59^{*} 10$ ) were not covered with those primer sets (Cowell et al., 1999; Van Esch et al., 2003) (Table 2). Therefore additional primers were designed to cover complete $\mathrm{VH}$ germline genes and designated them as $\mathrm{VH}^{*}{ }^{*} \mathrm{a}$ and $\mathrm{VH} 4{ }^{*} \mathrm{a}$.

The results from reverse transcriptase PCR with individual samples and from Q-PCR with pooled samples demonstrated that there were no significant differences in PCR profile between AS patients and control group, that was produced by PCR primer sets for $\mathrm{VH} 1 \mathrm{a}-\mathrm{VH} 6 \mathrm{a}$ and for $\mathrm{VH}^{*} \mathrm{a}$ (Figures $1 \mathrm{~A}$ and $1 \mathrm{~B}$ ). The results confirmed the previous study showing $\mathrm{VH} 3 \mathrm{a}$ was dominantly expressed (Voswinkel et al., 2001). Interestingly,
Table 1. Demographic and clinical characteristics of subjects.

\begin{tabular}{lcc}
\hline & AS $(n=8)$ & $\mathrm{HC}(n=9)$ \\
\hline Age (years) & $38.6 \pm 13.1$ & $30.2 \pm 2.3$ \\
Sex (M:F) & $7: 1$ & $8: 1$ \\
Disease duration (years) & $11.4 \pm 7.1$ & \\
History of uveitis & $3(37.5 \%)$ & \\
History of enthesitis & $2(25 \%)$ & \\
BASDAl $^{*}$ & $4.2 \pm 2.3$ & \\
BASFI $^{*}$ & $2.6 \pm 2.2$ & \\
${\text { ESR }(\mathrm{mm} / \mathrm{h})^{*}}_{\text {CRP }(\mathrm{mg} / \mathrm{dl})^{*}}$ & $37.0 \pm 35.8$ & \\
HLA-B27 positivity & $1.7 \pm 2.2$ & \\
\hline
\end{tabular}

AS, ankylosing spondylitis; HC, healthy controls; BASDAI, Bath Ankylosing Spondylitis Disease Activity Index; BASFI, Bath Ankylosing Spondylitis Functional Index. *Mean \pm SD.

$\mathrm{VH} 2^{*}$ genes represented by $\mathrm{VH} 2^{*}$ a forward primer were overexpressed exclusively in AS patients (patient sample numbers $4,5,6,7$, and 8 as shown in Figure 1A). Thus, Q-PCR with individual samples was performed to quantify the amount of $\mathrm{VH}{ }^{*}$ transcripts. Significant difference was shown in the level of expression of $\mathrm{VH}^{*}$ genes between healthy donors and AS patients (relative amount of mRNA of $\mathrm{VH} 2^{*}$ genes to human acidic ribosomal protein (HuPo), $0.68 \pm 0.55$ [mean $\pm \mathrm{SD}$ ] and $7.13 \pm 7.77$, respectively; $P<0.0001$; Figure 1C). There were no correlations of the expression level of $\mathrm{VH}^{*}$ with clinical variables such as sex, age, disease duration and inflammatory parameters (data not shown).

\section{Gene structure of VH2* PCR products}

The PCR products from samples demonstrating high expression level of $\mathrm{VH}^{*}$ genes were cloned and sequenced. Sequence analysis revealed a short fragment from CDC42 BPB genes incorporated into major part of cloned $\mathrm{VH} 2^{*} \mathrm{PCR}$ products from patient sample number $4,5,6,7$, and 8 . This is an intron fragment located in the region encompassing 252 bps (36096-36348) of 125-kb of CDC42 BPB which maps to $14 q 32.32$ (Figure 2) (Moncrieff et al., 1999) and is assumed to be incorporated in-between a short stretch of $\mathrm{VH} 2$ and DH6.

Another PCR using primers corresponding to sequences in the middle of the intron of CDC42 BPB gene and Ig constant regions $\left(C_{\mu}, C_{\gamma}\right.$ and $\left.C \varepsilon\right)$ was set up to confirm that the intron fragment from CDC42 BPB genes was indeed incorporated into Ig heavy chain gene segments (Figure 1D). The results demonstrated the expected band size, about 330 bps, which appeared exclusively by a $\mathrm{C} \varepsilon$ primer. Therefore these results imply that an intron 
Table 2. Oligonucleotide primers used to evaluate $\mathrm{VH}$ gene usage and confirm CDC42BPB inserted gene structure.

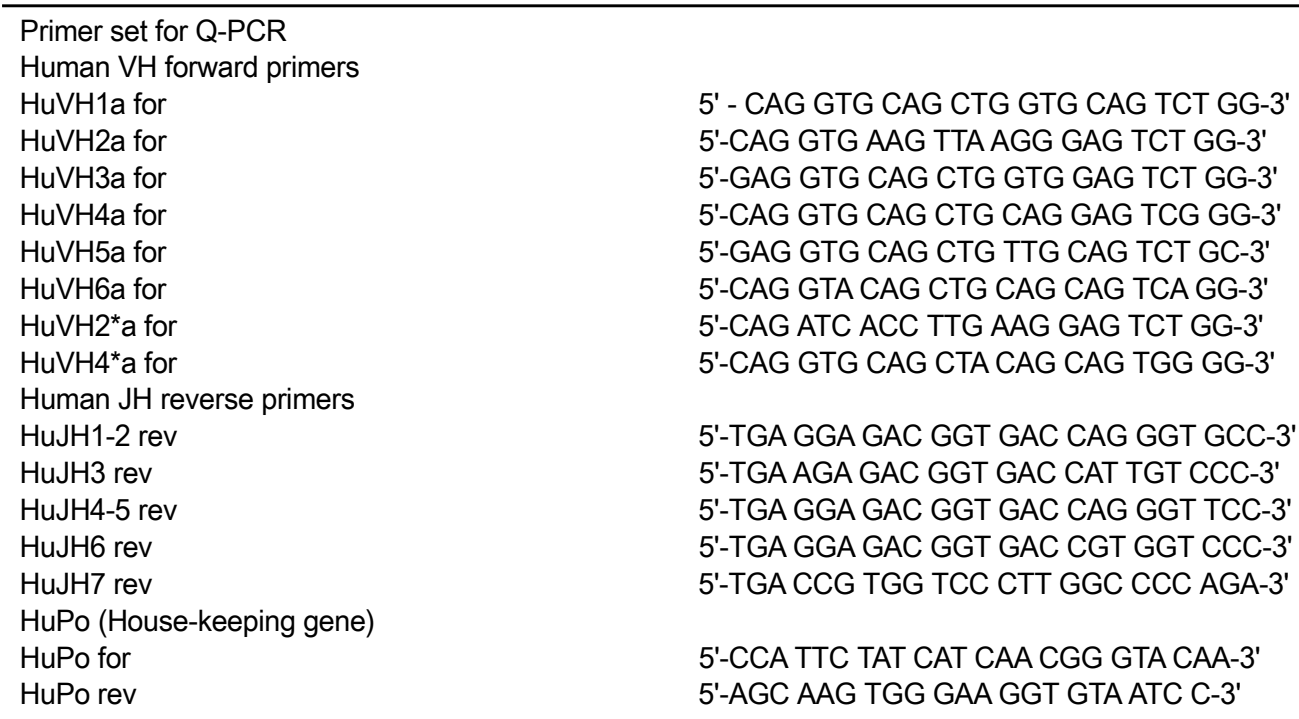

Primer set for second PCR

Human $\mathrm{VH} 2^{*}$ a forward primers with $\mathrm{Ncol}$ restriction sites $\mathrm{HuVH} 2^{*} \mathrm{a}-\mathrm{NcO} 1$

5'-AGC CGG CCA TGG CCG CAG ATC ACC TTG AAG GAG TCT GG-3

Human $\mathrm{JH}$ reverse primers with Xhol restriction sites HuJH1-2-Xho1

HuJH3-Xho1

HuJH4-5-Xho1

5'-TCC ACC GCT CGA GAC TGA GGA GAC GGT GAC CAG GGT GCC-3' 5'-TCC ACC GCT CGA GAC TGA AGA GAC GGT GAC CAT TGT CCC-3' 5'-TCC ACC GCT CGA GAC TGA GGA GAC GGT GAC CAG GGT TCC-3' 5'-TCC ACC GCT CGA GAC TGA GGA GAC GGT GAC CGT GGT CCC-3'

HuJH6-Xho1

HuJH7-Xho1

Primer set to confirm CDC42BPB insert

HuCDC42 BPB Forward primer

HuCDC42-FOR

Human $\mathrm{C}_{\mu}, \mathrm{C}_{\gamma}$ and $\mathrm{C}_{\varepsilon}$ reverse primer

$\mathrm{Hu} \mathrm{C}_{\mu}$ rev

$\mathrm{Hu} \mathrm{C}_{\gamma}$ rev

$\mathrm{Hu} \mathrm{C}_{\varepsilon}$ rev 5'-TCC ACC GCT CGA GAC TGA CCG TGG TCC CTT GGC CCC AGA-3'

\author{
5'-GAG CAC TGG CCA AGC ACT A-3' \\ 5'-TCC AGG AGA AAG TGA TGG AG-3' \\ 5'-GTC TTG GCA TTA TGC ACC TC-3' \\ 5'-CGG ATG GGC TCT GTG TGG-3'
}

fragment of the CDC42 BPB gene, suggested by sequence analysis, was incorporated in between $\mathrm{VH} 2$ and $\mathrm{DH} 6-\mathrm{JH} 3-\mathrm{C} \varepsilon$ of rearranged $\mathrm{lg}$ genes (Figure 1D).

\section{Discussion}

Immunoglobulins consist of the light (L) and heavy $(\mathrm{H})$ chains, each of which has variable and constant regions. The human $\mathrm{VH}$ segments are located in three loci; chromosome 14, 15 and 16 but only the chromosome 14 locus contains the $\mathrm{JH}$ segments that are essential for somatic generation of the $\mathrm{VH}$ genes.

As for $\mathrm{VH}$ germline gene usages in AS patients, a previous report demonstrated over-representation of $\mathrm{VH} 5$ and under-representation of $\mathrm{VH} 4$ from the AS synovial B lymphocytes compared with the germline representation (Voswinkel et al., 2001). In this study, we used a novel primer set including $\mathrm{VH} 2^{*} \mathrm{a}$, representing some of the IGHV2 genes in the VH2 germline gene family, which had been absent in the previous study. $\mathrm{VH}^{*}$ genes were overexpressed only in AS patients and the level of expression was significantly higher in $\mathrm{PB}$ of $\mathrm{AS}$ patients compared to those of healthy donors. It suggests that restricted germline gene family may be selected in $\mathrm{PB}$ of $\mathrm{AS}$ patients.

The Ig $V$ gene repertoire in PB was not compared with either synovial tissues or synovial fluid in the same patients in this study. The $\lg \mathrm{V}$ gene repertoire in $\mathrm{PB}$ may be different from that in inflammatory joints. PB contains a population of recirculating memory $B$ cells that have encountered a wide diversity of antigens over the patient's lifetime, whereas inflammatory joint tissues may have the subset of $B$ cells responding to antigen and undergoing antigen-driven response. Thus comparing Ig contents of synovial B cells with 
A

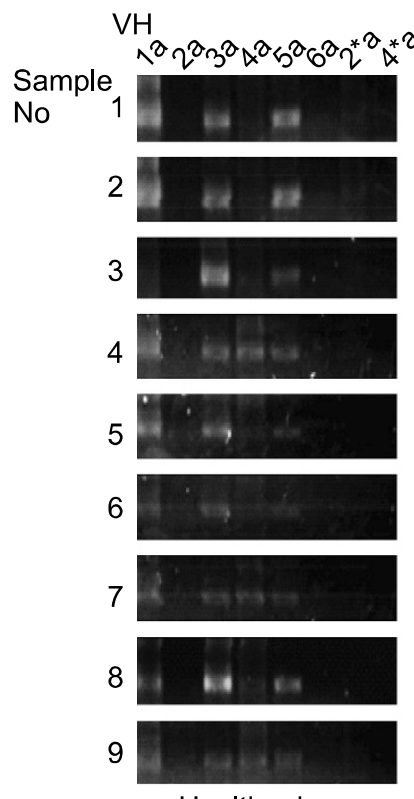

Healthy donors
$\mathrm{VH}$ $r^{2} 2^{2} 3^{2} x^{2} 6^{2} 6^{2} n^{* 2} x^{2}$ 1

2

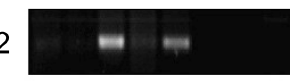

3

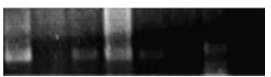

4

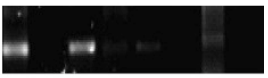

5

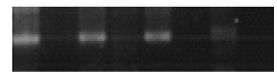

6

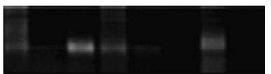

7

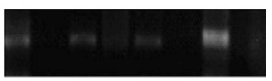

8

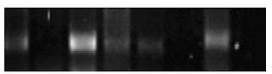

AS patients

\section{B}

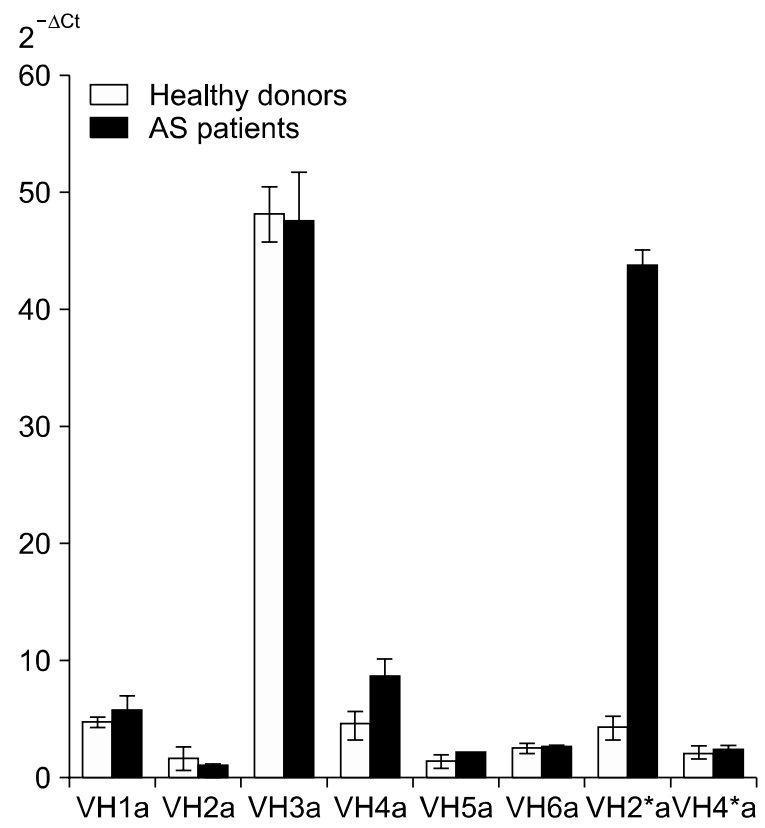

\section{C}

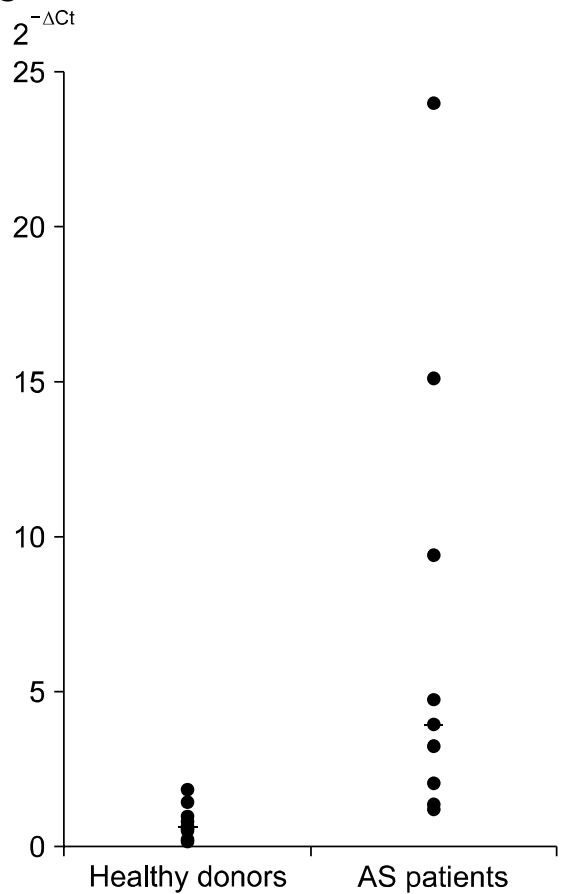

D

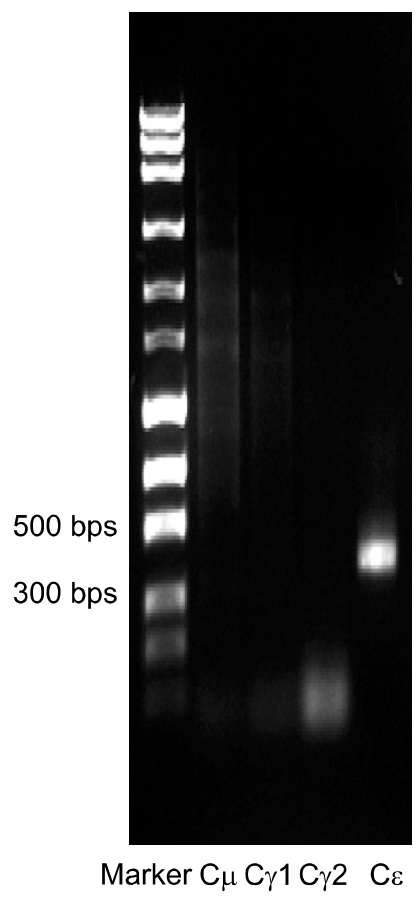

Figure 1. VH2 genes were overexpressed in AS patients. (A) Comparison of $\mathrm{VH}$ gene usages in PBMCs from healthy donors and AS patients. Reverse transcriptase PCR was performed with RNA from PBMCs of healthy donors and AS patients using primers shown in Table 2. VH2* genes were overexpressed exclusively in AS patients (patient sample number $4,5,6,7$ and 8 ). $n=9$ of healthy donors and 8 of AS patients. (B) The relative expression levels of patients and healthy donors' each VH gene. Q-PCR was performed with pooled CDNA from PBMC of healthy donors and AS patients using primers specific for VH1a-6a genes. The relative amount of transcripts of target genes compared to those of a housekeeping gene was calculated as follows; $\triangle \mathrm{Ct}$ $=\mathrm{Ct}_{\text {(experimental) }}-\mathrm{Ct}_{\text {(housekeeping), }} \mathrm{R}=2^{-(\triangle \mathrm{Ct})}$. The data shows the means and standard deviations of PCR amplication in triplicate. (C) Q-PCR was performed with individual cDNA from each PBMC of healthy donor and AS patient using primers specific for VH2* genes. The relative amount of mRNA of VH2* genes to HuPo was calculated as above. The relative amount of mRNA of VH2* genes to HuPo in AS patients was significantly higher compared to healthy donors $(P<0.0001)$. $n=9$ of healthy donors and 8 of AS patients. (D) CDC42 BPB intron sequences were inserted in Ig genes in AS patients. PCR was performed with cDNA from PBMCs of healthy donors and AS patients using primers specific for CDC42 BPB genes and lg C epsilon genes. 


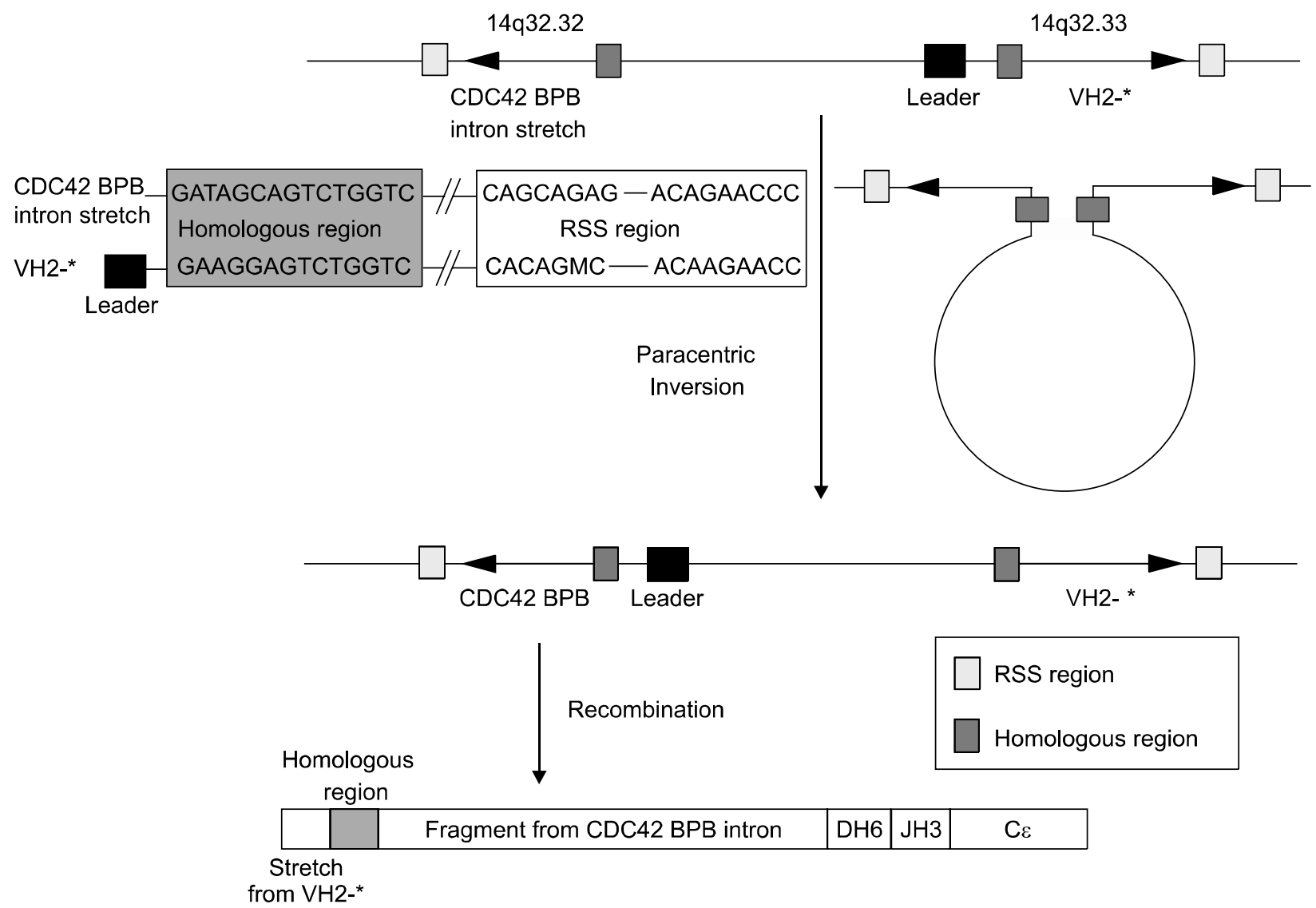

Figure 2. Proposed gene structure of rearranged $\mathrm{VH} 2^{*}$ genes in AS patients. CDC42 BPB intron fragment could be paracentrically inverted into VH2 genes. Both genes are located in chromosome 14q32. The sequence homology search revealed possible RSS sequences close to the inserted CDC42 $\mathrm{BPB}$ intron fragment. The resulted rearranged Ig gene has a part of the VH2 genes, CDC42 BPB intron sequences, $\mathrm{DH} 6, \mathrm{JH} 3$, and $\mathrm{C}_{\varepsilon}$ in order.

those of PB should be interesting.

Strikingly the sequence analysis and homology search of overexpressed $\mathrm{VH} 2^{*}$ PCR products revealed unexpected features of $\mathrm{VH}$ gene structure. In the sequences of $\mathrm{VH} 2{ }^{*} \mathrm{PCR}$ products, a short stretch of CDC42 BPB intron gene was found (Figure 2). It is worth noting that this intron segment is located in chromosome $14 q$ where human Ig $\mathrm{VH}$ gene locus is present (Cook et al., 1994). Ig gene rearrangement requires recombination signal sequences (RSS) that consist of a heptamer, 23 nucleotides (nts), and a nonamer in this order (Jung et al., 2006). A short stretch of intron sequences of CDC42 BPB was found between $\mathrm{VH}$ and $\mathrm{DH}$ genes. The $5^{\prime}$ end of this fragment includes homologous region (15 nucleotides) to that of the $\mathrm{VH} 2$ germline gene (Figure 2). Interestingly, further analysis of CDC42 BPB genomic sequences identified a nonamer of RSS, which is located following an insertion site of this fragment by 18 nucleotides, exists in CDC42 BPB genes. In addition, a heptamer-like sequence (CAGCAGAG), which has one $G$ base added feature to generally known heptamer of RSS (CACAGAG), also appears in the end of the inserted CDC42 BPB intron genes, as seen in Figure 2. This gene structure implies that unusual gene rearrangement or recombination may occur during construction of $\mathrm{VH}$ gene segments during $\mathrm{B}$ cell development in some of the AS patients. Paracentric inversion following recombination activating gene (RAG)- based recombination might be suggested to explain unique rearranged $\mathrm{VH} 2^{*}$ gene structure (Figure 2). However, it should be mentioned that this hypothesis does not perfectly fit in with the norm of RAG-based recombination as the distance between the heptamer and the nonamer in CDC42 BPB gene is shorter and the heptamer-like sequence in CDC42 BPB needs to have one base deletion to become proper heptamer for recombination. The questions how these unfitted features could be modified in some AS patients and whether the unique rearrangements were found only in Korean AS patients are still remaining. Further study is required to address these questions. 
To date, evidence that B cells are involved in AS/spondyloarthritis pathogenesis has been relatively scant. Nevertheless, B cells and plasma cells are consistently present in inflammatory lesions (McGonagle et al., 2002; Appel et al., 2006). In a recent open label phase-II clinical trial, rituximab, a chimeric monoclonal antibody against CD20 on the surface of B cells, showed significant efficacy in TNF-naïve patients with AS (Song et al., 2009). Our study, along with Voswinkel's work (Voswinkel et al., 2001), showed abnormal molecular event in B cells from AS patients. Taken together, these suggest that $B$ cells may play a role in developing AS. Since the autoantibodies are not identified in AS, B cells might contribute to AS/spondyloarthritis pathogenesis by (auto) antigen presentation to $T$ cells or cytokine release rather than by antibody production. In a mouse model of proteoglycan-induced arthritis, B cells contributed to the disease by presentation of autoantigen and subsequent $\mathrm{T}$ cell activation as well as by producing specific antibodies (O'Neill et al., 2005). Additional sequence analysis of rearranged $\mathrm{VH}^{*}$ gene structure is currently being performed, and it is planned to screen binding partners from serum of AS patient against this aberrant gene product. It would be also informative to determine whether the rearranged $\mathrm{lg}$ actually produces protein. However, it is possible that the aberrantly rearranged $\mathrm{lg}$ genes are not functional, thus no protein could be produced. Aberrant Ig transcripts could still affect other Ig protein production or composition in a way or another. Further investigations are required to verify that distinct rearrangement of $\lg \mathrm{VH}$ genes are involved in $\mathrm{B}$ cell development or function in terms of AS pathogenesis.

In conclusion, this study revealed $\mathrm{VH} 2$ overexpression and unique rearrangement in $\mathrm{lg} \mathrm{VH}$ genes from PB of AS patients. This may imply aberrant immunoglobulin gene rearrangement in $B$ cell occurs in Korean AS patients, which awaits further investigation.

\section{Methods}

\section{Subjects}

Peripheral blood (PB) was collected from 9 healthy controls and from 8 patients with AS who visited the rheumatology clinic at Gachon University Gil Hospital. The patients with AS met the Modified New York Criteria (van der Linden et al., 1984) and were taking non-steroidal anti-inflammatory drug and sulfasalazine regularly. Age, sex, disease duration, erythrocyte sedimentation rate (ESR), serum C reactive protein (CRP) and HLA-B27 positivity were assessed (Table 1 ). The validated Korean version of Bath AS Disease Activity Index (BASDAI) (Garrett et al., 1994) for AS patients were calculated when their PB was collected. The study was approved by Local Research Ethical Committee of Gachon University Gil Hospital and written informed consent was obtained from all the patients and healthy volunteers.

\section{Quantitative real-time PCR (Q-PCR)}

PB was collected into sterile, heparinized tubes and PB mononuclear cells (PBMCs) were isolated from whole blood using a Ficoll-Hypaque gradient (Cho et al., 2008). Total RNA was isolated from PBMCs by RNAeasy mini kit (Qiagen, Hilden, Germany) and cDNA was synthesized by Maxime $^{\text {TM }}$ RT PreMix (Oligo(dT)15 primer) Kit (Intron Biotechnology, Korea) following manufacturers' instructions. PCR and Q-PCR were performed with primers as shown in Table 2 (Cowell et al., 1999; Van Esch et al., 2003; Dheda et al., 2004). For thorough representation of VH germline genes, two novel VH forward primers, which we refer to as $\mathrm{VH}^{*} \mathrm{a}$ and $\mathrm{VH} 4^{*} \mathrm{a}$ forward primers for Q-PCR, were added to VH PCR primer sets used in previous studies (Voswinkel et al., 2001). The sequences of $\mathrm{VH} 2 \mathrm{a}$ and $\mathrm{VH} 4 \mathrm{a}$ forward primers previously used were different from those for $\mathrm{VH}^{*} \mathrm{a}$ and $\mathrm{VH} 4^{*} \mathrm{a}$, as shown in Table 1. Primers for human acidic ribosomal protein (HuPo) gene, as a house-keeping gene, were also used since it is known to be more reliable than $\beta$-actin gene as control for the Q-PCR in PBMC (Dheda et al., 2004). PCR mixture without DNA was included in each experiment as negative control. The amplification condition was $95^{\circ} \mathrm{C}$ for $30 \mathrm{~s}$, $50-60^{\circ} \mathrm{C}$ for $1 \mathrm{~min}$, and $72^{\circ} \mathrm{C}$ for $1 \mathrm{~min}$ for $30-40$ cycles. Primers were produced by MWG (Ebersberg, Germany). Reagents for Q-PCR were purchased from Stratagene (La Jolla, USA). PCR products were analyzed by gel electrophoresis or by MxPro ${ }^{\mathrm{TM}}$ QPCR software (Stratagene, La Jolla). The relative amount of transcripts of target genes compared to those of a housekeeping gene was calculated as follows; $\Delta \mathrm{tCt}=\mathrm{Ct}_{\text {(experimental) }}-\mathrm{Ct}_{\text {(housekeeping) }}, \mathrm{R}=2^{-(\Delta \mathrm{Ct})}$.

\section{Sequence analysis}

The second PCR was performed with Q-PCR products from selected $\mathrm{VH}^{*}$ overexpressed patient samples (number 4, 5, 6, 7, and 8) as a template to introduce $\mathrm{Ncol}$ and Xhol site at $5^{\prime}$ and $3^{\prime}$ end of first PCR products, respectively. The PCR products were cloned into pIT2 vectors (Enever et al., 2005) and 60-80 colonies were selected to confirm inserted genes by PCR screening using primer set for second PCR (Table 1). Approximately 20 samples of each group were analyzed by sequencing (MWG, Germany). The sequence results were analyzed by homology comparison with Ig Blast databases (http://www. ncbi.nlm.nih.gov/igblast) and IMGT databases (http://imgt. cines.fr).

To identify incorporation of CDC42 BPB intron fragments, PCR amplification was performed with primers for CDC42 BPB intron gene and human Ig constant region (C) genes (Table 1). Reaction conditions were initial denaturation at $95^{\circ} \mathrm{C}$ for $15 \mathrm{~min}$, followed by 30 cycles of $94^{\circ} \mathrm{C}$ for $30 \mathrm{~s}, 58^{\circ} \mathrm{C}$ for $30 \mathrm{~s}$ and $72^{\circ} \mathrm{C}$ for $1 \mathrm{~min}$, and then $72^{\circ} \mathrm{C}$ for $10 \mathrm{~min}$ for final extension. PCR products were 
analyzed by $2 \%$ agarose gel electrophoresis.

\section{Statistics}

A non-parametric statistic method, two tailed MannWhitney $U$ test was performed to test the significance of differences in mRNA amount of individual VH gene families between AS patients and healthy volunteers (SPSS, Ver. 12.0. Chicago, IL). To test for correlations between the expression level of $\mathrm{VH}^{*}$ a genes and clinical variables, Spearman's rank correlation coefficient was used.

\section{Acknowledgements}

We thank Dr. T.H Rabbitts (LIMM, United Kingdom) for helpful discussion on chromosomal inversion. This study was funded by Korea Institute of Science and TechnologyEurope basic research program. HJB was supported by Korean Institute of Medicine.

\section{References}

Appel H, Kuhne M, Spiekermann S, Ebhardt H, Grozdanovic Z, Kohler D, Dreimann M, Hempfing A, Rudwaleit M, Stein $\mathrm{H}$, Metz-Stavenhagen $\mathrm{P}$, Sieper J, Loddenkemper C. Immunohistologic analysis of zygapophyseal joints in patients with ankylosing spondylitis. Arthritis Rheum 2006; 54:2845-51

Baeten D, Demetter P, Cuvelier CA, Kruithof E, Van Damme $\mathrm{N}$, De Vos M, Veys EM, De Keyser F. Macrophages expressing the scavenger receptor CD163: a link between immune alterations of the gut and synovial inflammation in spondyloarthropathy. J Pathol 2002;196:343-50

Breban M, Fernandez-Sueiro JL, Richardson JA, Hadavand RR, Maika SD, Hammer RE, Taurog JD. T cells, but not thymic exposure to HLA-B27, are required for the inflammatory disease of HLA-B27 transgenic rats. J Immunol 1996;156:794-803

Brewerton DA, Hart FD, Nicholls A, Caffrey M, James DC, Sturrock RD. Ankylosing spondylitis and HL-A 27. Lancet 1973;1:904-7

Cho ML, Jung YO, Kim KW, Park MK, Oh HJ, Ju JH, Cho YG, Min JK, Kim SI, Park SH, Kim HY. IL-17 induces the production of IL-16 in rheumatoid arthritis. Exp Mol Med 2008;40:237-45

Cook GP, Tomlinson IM, Walter G, Riethman H, Carter NP, Buluwela L, Winter G, Rabbitts TH. A map of the human immunoglobulin $\mathrm{VH}$ locus completed by analysis of the telomeric region of chromosome 14q. Nat Genet 1994;7: 162-8

Cowell LG, Kim HJ, Humaljoki T, Berek C, Kepler TB. Enhanced evolvability in immunoglobulin $\mathrm{V}$ genes under somatic hypermutation. J Mol Evol 1999;49:23-6

De Keyser F, Elewaut D, De Vos M, De Vlam K, Cuvelier C, Mielants $\mathrm{H}$, Veys EM. Bowel inflammation and the spondyloarthropathies. Rheum Dis Clin North Am 1998; 24:785-813, ix-x
Dheda K, Huggett JF, Bustin SA, Johnson MA, Rook G, Zumla A. Validation of housekeeping genes for normalizing RNA expression in real-time PCR. Biotechniques 2004;37: $112-4,116,118-9$

Dorner T, Hansen A, Jacobi A, Lipsky PE. Immunglobulin repertoire analysis provides new insights into the immunopathogenesis of Sjogren's syndrome. Autoimmun Rev 2002;1:119-24

Enever C, Tomlinson IM, Lund J, Levens M, Holliger P. Engineering high affinity superantigens by phage display. $\mathrm{J}$ Mol Biol 2005;347:107-20

Ermel RW, Kenny TP, Wong A, Chen PP, Malyj W, Robbins $\mathrm{DL}$. Analysis of the molecular basis of synovial rheumatoid factors in rheumatoid arthritis. Clin Immunol Immunopathol 1997;84:307-17

Foreman AL, Van de Water J, Gougeon ML, Gershwin ME. $B$ cells in autoimmune diseases: insights from analyses of immunoglobulin variable (lg V) gene usage. Autoimmun Rev 2007;6:387-401

Garrett S, Jenkinson T, Kennedy LG, Whitelock H, Gaisford $P$, Calin A. A new approach to defining disease status in ankylosing spondylitis: the Bath Ankylosing Spondylitis Disease Activity Index. J Rheumatol 1994;21:2286-91

Isenberg $D$, Spellerberg $M$, Williams $W$, Griffiths $M$, Stevenson F. Identification of the 9G4 idiotope in systemic lupus erythematosus. Br J Rheumatol 1993;32:876-82

Jandus C, Bioley G, Rivals JP, Dudler J, Speiser D, Romero $P$. Increased numbers of circulating polyfunctional Th17 memory cells in patients with seronegative spondylarthritides. Arthritis Rheum 2008;58:2307-17

Jung D, Giallourakis C, Mostoslavsky R, Alt FW. Mechanism and control of $\mathrm{V}(\mathrm{D}) \mathrm{J}$ recombination at the immunoglobulin heavy chain locus. Annu Rev Immunol 2006;24:541-70

May E, Dorris ML, Satumtira N, Iqbal I, Rehman MI, Lightfoot E, Taurog JD. CD8 alpha beta T cells are not essential to the pathogenesis of arthritis or colitis in HLA-B27 transgenic rats. J Immunol 2003;170:1099-105

McGonagle D, Marzo-Ortega H, O'Connor P, Gibbon W, Hawkey P, Henshaw K, Emery P. Histological assessment of the early enthesitis lesion in spondyloarthropathy. Ann Rheum Dis 2002;61:534-7

Moncrieff CL, Bailey ME, Morrison N, Johnson KJ. Cloning and chromosomal localization of human Cdc42-binding protein kinase beta. Genomics 1999;57:297-300

O'Neill SK, Shlomchik MJ, Glant TT, Cao Y, Doodes PD, Finnegan A. Antigen-specific B cells are required as APCs and autoantibody-producing cells for induction of severe autoimmune arthritis. J Immunol 2005;174:3781-8

Robbins DL, Kenny TP, Coloma MJ, Gavilondo-Cowley JV, Soto-Gil RW, Chen PP, Larrick JW. Serologic and molecular characterization of a human monoclonal rheumatoid factor derived from rheumatoid synovial cells. Arthritis Rheum 1990;33:1188-95

Schlosstein L, Terasaki PI, Bluestone R, Pearson CM. High association of an HL-A antigen, W27, with ankylosing 
spondylitis. N Engl J Med 1973;288:704-6

Shen H, Goodall JC, Hill Gaston JS. Frequency and phenotype of peripheral blood Th17 cells in ankylosing spondylitis and rheumatoid arthritis. Arthritis Rheum 2009; 60:1647-56

Sims GP, Shiono H, Willcox N, Stott DI. Somatic hypermutation and selection of $B$ cells in thymic germinal centers responding to acetylcholine receptor in myasthenia gravis. J Immunol 2001;167:1935-44

Song I, Heldmann F, Rudwaleit M, Listing J, Appel H, Bogdan $M$, Braun J, Sieper J. Major clinical response of rituximab in active TNF-blocker-naive patients with anklyosing spondylitis but not in TNF-blocker-failure patients- an open label clinical trial. Ann Rheum Dis 2009;68(suppl 3):74

Stevenson FK, Longhurst C, Chapman CJ, Ehrenstein M, Spellerberg MB, Hamblin TJ, Ravirajan CT, Latchman D, Isenberg D. Utilization of the VH4-21 gene segment by anti-DNA antibodies from patients with systemic lupus erythematosus. J Autoimmun 1993;6:809-25

Taurog JD, Richardson JA, Croft JT, Simmons WA, Zhou M,
Fernandez-Sueiro JL, Balish E, Hammer RE. The germfree state prevents development of gut and joint inflammatory disease in HLA-B27 transgenic rats. J Exp Med 1994;180: 2359-64

van der Linden S, Valkenburg HA, Cats A. Evaluation of diagnostic criteria for ankylosing spondylitis. A proposal for modification of the New York criteria. Arthritis Rheum 1984;27:361-8

Van Esch WJ, Reparon-Schuijt CC, Hamstra HJ, Van Kooten C, Logtenberg T, Breedveld FC, Verweij CL. Human IgG Fc-binding phage antibodies constructed from synovial fluid $C D 38+B$ cells of patients with rheumatoid arthritis show the imprints of an antigen-dependent process of somatic hypermutation and clonal selection. Clin Exp Immunol 2003;131: 364-76

Voswinkel J, Weisgerber K, Pfreundschuh M, Gause A. B lymphocyte involvement in ankylosing spondylitis: the heavy chain variable segment gene repertoire of $B$ lymphocytes from germinal center-like foci in the synovial membrane indicates antigen selection. Arthritis Res 2001;3:189-95 